\title{
Acetyl-CoA Production and Utilization during Growth of the Facultative Methylotroph Pseudomonas AM1 on Ethanol, Malonate and 3-Hydroxybutyrate
}

\author{
By I. J. TAYLOR* AND C. ANTHONY \\ Department of Physiology and Biochemistry, \\ The University, Southampton $\mathrm{SO}_{9}{ }_{3} \mathrm{TU}$ \\ (Received 9 December 1975; revised 23 February 1976)
}

SUMMAR Y

In Pseudomonas AMI, conversion of 3-hydroxybutyrate to acetyl-CoA is mediated by an inducible 3-hydroxybutyrate dehydrogenase, an acetoacetate: succinate coenzyme A transferase (specific for succinyl-CoA) and an inducible $\beta$-ketothiolase. Ethanol is oxidized to acetate by the same enzymes as are involved in methanol oxidation to formate. An inducible acetyl-CoA synthetase has been partially purified and characterized; it is essential for growth only on ethanol, malonate and acetate plus glyoxylate, as shown by the growth characteristics of a mutant (ICT54) lacking this enzyme. Free acetate is not involved in the assimilation of acetyl-CoA, and hydroxypyruvate reductase is not involved in the oxidation of acetyl-CoA to glyoxylate during growth on 3-hydroxybutyrate. A mutant (ICT5I), lacking 'malate synthase' activity, has been isolated and its characteristics indicate that this activity is normally essential for growth of Pseudomonas AMI on ethanol, malonate and 3-hydroxybutyrate, but not for growth on other substrates such as pyruvate, succinate and $C_{1}$ compounds. The growth properties of a revertant (ICT5IR) and of a mutant lacking malyl-CoA lyase (PCT57) indicate that an alternative route must exist for assimilation of compounds metabolized exclusively by way of acetyl-CoA.

\section{INTRODUCTION}

In Pseudomonas AmI, the malate synthase pathway has been proposed as a route for the assimilation of substrates that are metabolized to acetyl-CoA or acetate: these include 3-hydroxybutyrate, ethanol, malonate, lactate and pyruvate (Salem et al., 1973 b; Dunstan \& Anthony, 1973; Anthony, 1975a). During operation of this pathway, one molecule of acetyl-CoA (or acetate) is oxidized to glyoxylate [in reactions also occurring as part of the same pathway during growth on $\mathrm{C}_{1}$ compounds (Dunstan \& Anthony, 1973)]. The glyoxylate then condenses with a second molecule of acetyl-CoA in a reaction catalysed by malate synthase to give malate. It has been suggested that the malate synthase activity may result from the sequential action of malyl-CoA lyase and malyl-CoA hydrolase or transferase (Salem, Hacking \& Quayle, I973a) and recent results show that this is indeed the case (Cox \& Quayle, I976).

The present paper describes investigations designed to determine the pathways involved in the formation of acetyl-CoA from ethanol, malonate and 3-hydroxybutyrate; to distinguish between acetate and acetyl-CoA as precursors of glyoxylate; and to determine whether or not hydroxypyruvate reductase is involved in the oxidation of acetate to glyoxylate in Pseudo-

* Present address: ICI Ltd, Agricultural Division, P.O. Box 6, Billingham, Teesside TS2 ILD. 
monas AMI. The importance of acetyl-CoA synthetase for growth on ethanol and malonate has been demonstrated by the isolation and characterization of a mutant lacking this enzyme, and the importance of malate synthase activity for normal growth of Pseudomonas AMI on ethanol, malonate and 3-hydroxybutyrate has been confirmed by the isolation and study of a mutant lacking this activity. A preliminary report of these two mutants has been published (Taylor \& Anthony, 1975).

\section{METHODS}

Maintenance, growth and harvesting of bacteria. Methods were as previously described (Anthony, 1975b). Carbon sources included in the basal salts medium were used at a concentration of $0.2 \%$ except for: methanol and ethanol $(0.4 \%) ; 3$-hydroxybutyrate, malonate and acetate $(0.1 \%)$; glyoxylate $(5 \mathrm{~mm})$.

Isolation of mutants ICT54, ICT5 I and ICT5IR. Mutants ICT54 and ICT5I were isolated by a method based on that of Heptinstall \& Quayle (1970), designed to select for mutants able to grow on malate but not on a combination of acetate (O. I \%) plus glyoxylate ( $5 \mathrm{~mm}$ ). Bacteria treated with $N$-methyl- $N^{\prime}$-nitro- $N$-nitrosoguanidine (NTG) were expressed in malate medium and then treated three times with benzylpenicillin ( $1000 \mathrm{u} . / \mathrm{ml}$ medium) in the presence of acetate plus glyoxylate. Mutants isolated by this selection procedure included mutant ICT54 which lacked acetyl-CoA synthetase and mutant ICT5I which lacked malate synthase activity. Mutant ICT5I R was isolated on (acetate plus glyoxylate)-agar plates from a streptomycin-resistant derivative of mutant ICT5I, by the method described by Taylor \& Anthony (1976). All bacterial strains, including mutant 20BL which was a gift from Professor J. R. Quayle, were maintained on succinate-agar slopes at $2{ }^{\circ} \mathrm{C}$.

Preparation of cell-free extracts, determination of protein, and enzyme assays. The growth characteristics of mutant bacteria were determined in liquid media as described by Taylor $\&$ Anthony (1976). The methods used for determination of protein and preparation of cell-free extracts were as described by Anthony (1975b). All spectrophotometric enzyme assays were carried out using a Pye-Unicam SPI 800 recording spectrophotometer at $25{ }^{\circ} \mathrm{C}$. The following enzymes were assayed by published procedures: 3-hydroxybutyrate dehydrogenase, EC. I.I.I.30 (Schuster \& Doudoroff, 1962); acetoacetate:succinate CoA-transferase, EC. $2.8 \cdot 3 \cdot 5$ (Stern et al., 1956); $\beta$-ketothiolase, EC. 2.3 .1 .9, cleavage reaction (Senior \& Dawes, 1973), condensation reaction (Oeding \& Schlegel, 1973); acetoacetyl-CoA reductase, EC. I.I.I.36 (Ritchie, Senior \& Dawes, I97I); succinyl-CoA synthetase, EC. 6.2.I.5 (Kaufman, I955); malyl-CoA lyase (Salem et al., I 973a); acetokinase, EC. 2.7.2 . I (Rose, 1955); CoA,NAD-dependent aldehyde dehydrogenase (Dawes \& Foster, I956). Malate synthase activity was assayed by the method of Dixon \& Kornberg (I959).

Assay and partial purification of acetyl-CoA synthetase. Acetyl-CoA synthetase (EC. 6.2. I. I) was assayed by the hydroxamate method of Jones \& Lipmann (I955) except that the incubation temperature was $40^{\circ} \mathrm{C}$ instead of $30^{\circ} \mathrm{C}$. Acetyl-CoA synthetase activity was partially purified by the following method. A crude sonic extract of bacteria grown on 3-hydroxybutyrate was dialysed against $20 \mathrm{~mm}$-phosphate buffer $\mathrm{pH} 7.0$ and treated with protamine sulphate $(\mathrm{I} \cdot 8 \% \mathrm{w} / \mathrm{v})$ at $2{ }^{\circ} \mathrm{C}$ until precipitation was complete. Precipitated protein and nucleic acids were removed by centrifuging. The supernatant liquid was heated at $60{ }^{\circ} \mathrm{C}$ for $15 \mathrm{~min}$, precipitated protein was again removed by centrifuging, and the supernatant was treated at $20^{\circ} \mathrm{C}$ with solid ammonium sulphate to obtain a fraction that precipitated at between $52 \%$ and $75 \%$ ammonium sulphate saturation. The precipitate was dissolved in $20 \mathrm{~mm}$-phosphate buffer $\mathrm{pH} 7 \cdot 0$ to give a protein concentration of about Io $\mathrm{mg} \mathrm{ml}^{-1}$. This fraction, which was free of succinyl-CoA synthetase activity, was further 
purified, to remove adenylate kinase, by gel-filtration on a column $(1 \cdot 5 \times 23 \mathrm{~cm})$ of Sephadex Gi50.The column was equilibrated with $20 \mathrm{~mm}$-phosphate buffer and proteins were eluted with the same buffer at room temperature.

Crude extracts, and partially purified extracts containing adenylate kinase activity, catalysed the production of ADP in an assay mixture containing ( $\mu \mathrm{mol}$, in a total volume of $3.0 \mathrm{ml}$ ): coenzyme A, 4; ATP, 2; sodium acetate, 20; phosphate buffer $\mathrm{pH} \mathrm{7.4,} 100$; $\mathrm{MgCl}_{2}$, I0; reduced glutathione, I0; NADH, 2.5; phosphoenolpyruvate, 5; pyruvate kinase and lactate dehydrogenase, Io units each; and acetyl-CoA synthetase fraction, 50 to $200 \mu \mathrm{g}$ protein (added to start the reaction). Adenylate kinase was assayed by the above method except that acetate and coenzyme A were replaced by AMP (I $\mu \mathrm{mol}$ ). Acetyl-CoA was identified as a product of acetyl-CoA synthetase by coupling its formation to NADH production in the presence of $\mathrm{NAD}^{+}$, malate, malate dehydrogenase and citrate synthase. The assay mixture contained $(\mu \mathrm{mol}$, in $2.0 \mathrm{ml})$ : Tris- $\mathrm{HCl}$ buffer $\mathrm{pH} 7 \cdot 4,200$; sodium malate, 20; sodium acetate, 20 ; coenzyme A, O.I; ATP, Io; $\mathrm{MgCl}_{2}, \mathrm{IO} ; \mathrm{NAD}^{+}, \mathrm{I}$; and acetyl-CoA synthetase fraction, $50 \mu \mathrm{g}$. Malate dehydrogenase (20 units) was added, and $E_{340}$ was monitored for 2 to $3 \mathrm{~min}$ before the addition of citrate synthase ( 5 units). The rate of production of NADH in the absence of citrate synthase was subtracted from the final rate and was equivalent to approximately $\mathrm{I} 20 \mathrm{nmol}$ acetyl-CoA produced/min per $\mathrm{mg}$ protein.

Incorporation of $\left[U-{ }^{14} \mathrm{C}\right]$ acetate into wild-type Pseudomonas $\mathrm{AMI}$, and mutants $\mathrm{ICT} 54$ and 2OBL, grown on 3-hydroxybutyrate. Cultures of bacteria were incubated with $\left[\mathrm{U}^{14} \mathrm{C}\right]$ acetate for I min and radioactive compounds were extracted with boiling aqueous ethanol according to the method of Dunstan, Anthony \& Drabble (I972a). After this time, the distribution of radioactivity amongst the non-volatile ethanol-soluble components of Pseudomonas AMI and mutant $20 \mathrm{BL}$ had reached equilibrium.

Chromatographic analysis of radioactive compounds. Ethanolic suspensions containing radioactive compounds were evaporated to dryness under reduced pressure at $35{ }^{\circ} \mathrm{C}$, resuspended in $0.0 \mathrm{I} \mathrm{M}-\mathrm{HCl}(0.5 \mathrm{ml})$ and applied to Dowex columns (IO $\times 0.6 \mathrm{~cm}, \mathrm{H}^{+}$ form). Neutral and acidic compounds were eluted with water ( $(10 \mathrm{ml})$ and basic compounds with $2 \mathrm{M}-\mathrm{NH}_{4} \mathrm{OH}(4.0 \mathrm{ml})$. These fractions were evaporated to dryness, dissolved in $20 \%$ $(\mathrm{v} / \mathrm{v})$ ethanol $(0.3 \mathrm{ml})$ and spotted on to Whatman no. I chromatography paper (dimensions $20 \times 57 \mathrm{~cm})$. The acidic fractions were run in ethanol/ammonia/water $(16: 1: 3$, by vol.), and compared with a mixture of standard carboxylic acids $(30 \mu \mathrm{g}$ each of citric, malic, succinic, fumaric and glycollic acids) run on either side of the test samples. Basic compounds were separated in phenol/ammonia/water $(200 \mathrm{ml}$ water-saturated phenol: $\mathrm{I} \mathrm{ml}$ $\mathrm{NH}_{3}$ ) and compared with a standard mixture of the following amino acids (6 $\mu \mathrm{g}$ each): alanine, glycine, serine, aspartic and glutamic acids.

After drying the chromatograms, strips containing the standard amino or carboxylic acids were cut off and stained. Carboxylic acids were stained with acridine $(0.1 \%, \mathrm{w} / \mathrm{v})$ in $99.5 \%$ ethanol, and appeared as yellow spots which fluoresced under u.v. light. Amino acids were stained with ninhydrin $(0.5 \%, \mathrm{w} / \mathrm{v})$ in acetone: after drying, the colour was developed for a few minutes at $110^{\circ} \mathrm{C}$ and amino acids appeared as blue/purple spots.

Radioactive compounds were detected with a Dunnschicht II chromatogram scanner. Areas of the chromatogram corresponding to peaks of radioactivity were cut out, placed in water $(2.0 \mathrm{ml})$ and shaken for $5 \mathrm{~min}$. The paper was removed and a sample of the eluant was counted in NE 250 scintillant. All counting was carried out in a Philips liquid scintillation analyser programmed for automatic quench correction.

The position of the radioactive peaks compared with the positions of the standards suggested the identity of the labelled compounds. This was confirmed by co-chromatography 
with authentic standards in the original solvent and in a second solvent. The second solvent was butanol/acetic acid/water (12:3:5, by vol.) for both amino and carboxylic acids.

Incorporation of radioactivity from $\left[U_{-14}{ }^{14} \mathrm{C}\right]$ acetate into growing cultures of bacteria. Cultures $(200 \mathrm{ml})$ were shaken at $30{ }^{\circ} \mathrm{C}$ in Erlenmeyer flasks $(500 \mathrm{ml})$, fitted with side arms for assessment of growth by following the extinction at $650 \mathrm{~nm}$. The medium contained 3-hydroxybutyrate $(0 . \mathrm{I} \%)$, to which $2 \mu \mathrm{Ci}$ of $\left[\mathrm{U}-{ }^{14} \mathrm{C}\right]$ acetate and non-radioactive acetate (final concentration, $2 \mathrm{~mm}$ ) were added once the cells had started to grow exponentially. Samples containing 0.2 to $0.6 \mathrm{mg}$ dry weight equivalent of organisms were withdrawn at intervals throughout growth and collected on a membrane filter, previously washed with water and sodium acetate. The bacteria were washed with acetate $(2 \times 5 \mathrm{ml}, 0 \cdot \mathrm{I} \mathrm{M})$ and water $(2 \times 5 \mathrm{ml})$, transferred on the filters to scintillation vials, and dissolved in NE 250 scintillant ( $10 \mathrm{ml}$ ) for estimation of radioactivity. Incorporation of radioactivity is expressed as specific activity (d.p.m./ $\mu$ g dry wt bacteria).

Chemicals. All chemicals were obtained from BDH except: coenzyme A (lithium salt) was from PL Biochemicals Inc., Milwaukee, U.S.A.; diketone (acetoacetic anhydride), Dowex $50 \mathrm{~W}\left(\mathrm{H}^{+}\right.$-form), $\mathrm{NADP}^{+}, \mathrm{NAD}^{+}, \mathrm{NADPH}, \mathrm{NADH}$, citrate synthase, malate dehydrogenase, pyruvate kinase and lactate dehydrogenase were from Sigma; glyoxylic acid monohydrate and $N$-methyl- $N^{\prime}$-nitro- $N$-nitrosoguanidine (NTG) were from Koch-Light; and Sephadex Gi5o was from Pharmacia.

Acetyl-CoA and acetoacetyl-CoA were prepared by the reaction of coenzyme A with the respective anhydrides of acetate and acetoacetate according to the methods of Srere (I969) and Simon \& Shemin (1953) respectively. [U-14 C]acetate from The Radiochemical Centre, Amersham, Buckinghamshire, was purified by the method of Dunstan et al. (1972a). (2S)-4-Malyl-CoA was a gift from Professor J. R. Quayle.

NE 250 scintillation fluid was obtained from Nuclear Enterprises Ltd, Beenham, Berkshire.

\section{RESULTS}

The formation of acetyl-CoA during growth of Pseudomonas AM I on 3-hydroxybutyrate, ethanol and malonate

The interconversion of 3-hydroxybutyrate and acetyl-CoA. The first enzyme involved in 3-hydroxybutyrate oxidation is an $\mathrm{NAD}^{+}$-specific 3-hydroxybutyrate dehydrogenase which was induced between 2.5 and I0-fold during growth of Pseudomonas AMI on 3-hydroxybutyrate compared with its level during growth on other substrates (Table 1 ).

The specific activities of the second enzyme, acetoacetate: succinate CoA-transferase, showed much less variation with carbon source than 3 -hydroxybutyrate dehydrogenase (Table I). The transferase was assayed by following the disappearance of acetoacetyl-CoA on addition of succinate to the reaction mixture. The following compounds were inactive as replacements for succinate in extracts prepared from bacteria grown in 3-hydroxybutyrate or methanol: malate, acetate, propionate, glycollate and formate. As these compounds were not activated by transfer of coenzyme A from acetoacetyl-CoA, it can be concluded that, in the direction of acetoacetate activation, the enzyme is specific for succinyl-CoA.

The final enzyme for the oxidation of 3 -hydroxybutyrate to acetyl-CoA is an inducible $\beta$-ketothiolase (Table I). The ratio of specific activities was constant whether assayed in the direction of acetoacetyl-CoA cleavage or acetyl-CoA condensation, the rate of cleavage being about four times that of condensation. The constant ratio demonstrates that one enzmye is involved in both directions and suggests that $\beta$-ketothiolase is also involved in poly-3-hydroxybutyrate biosynthesis in Pseudomonas AMI. The polymer is the only carbon 


\section{Table I. Specific activities of enzymes of 3-hydroxybutyrate metabolism in extracts of Pseudomonas AMI grown on various carbon sources}

Bacteria were harvested in the mid-exponential phase of growth and enzymes were assayed as described in Methods. Enzyme levels are expressed as $\mathrm{nmol} / \mathrm{mg}$ protein per min, and are the average of results from at least two separate extracts.

\section{Enzyme}

3-Hydroxybutyrate dehydrogenase Acetoacetate: succinate CoAtransferase

$\beta$-Ketothiolase (condensation)

Acetoacetyl-CoA reductase

\begin{tabular}{ccccc}
\multicolumn{4}{c}{ Growth substrate } \\
$\begin{array}{c}\text { 3-Hydroxy- } \\
\text { butyrate }\end{array}$ & Succinate & Methanol & Ethanol & Lactate \\
350 & 146 & $66 \cdot 5$ & $33 \cdot 2$ & 145 \\
$91 \cdot 5$ & $70 \cdot 5$ & $41 \cdot 3$ & $36 \cdot 0$ & $95 \cdot 0$ \\
310 & $87 \cdot 0$ & $75 \cdot 4$ & $81 \cdot 5$ & 126 \\
320 & 356 & 196 & 166 & 183
\end{tabular}

and energy reserve in this bacterium and forms between 3 and $8 \%$ of its dry weight during growth on methanol, ethanol, malonate, 3-hydroxybutyrate, lactate and succinate (Taylor, 1975). The substrate for polymerization of 3-hydroxybutyrate is not the free acid but 3hydroxybutyryl-CoA, which is produced by reduction of acetoacetyl-CoA. The acetoacetylCoA reductase catalysing this reaction was shown to be present in extracts of Pseudomonas AMI and it had similar specific activities on all growth substrates (Table I). The rate with NADH was Io times that measured with NADPH.

The oxidation of ethanol to acetyl-CoA. In Pseudomonas AMI, ethanol is oxidized to acetaldehyde by the methanol dehydrogenase which interacts with the cytochrome chain at the level of cytochrome $c$ (Anthony, 1975 b; Widdowson \& Anthony, 1975).

No nicotinamide-nucleotide-linked aldehyde dehydrogenase could be detected in extracts of ethanol-grown Pseudomonas AMI which contained no NAD ${ }^{+}$, CoA-dependent acetaldehyde dehydrogenase, as is found in ethanol-grown Hyphomicrobium x (Attwood \& Harder, 1974). Acetaldehyde is thus presumably oxidized to the level of free acetate by the $\mathrm{NAD}(\mathrm{P})^{+}$-independent aldehyde dehydrogenase which leads to reduction of the cytochrome chain at the level of cytochrome $b$ (Widdowson \& Anthony, 1975). The low activity of this enzyme probably accounts for the acetaldehyde that accumulates during the rather slow growth of Pseudomonas AMI on ethanol. The activation of the acetate produced by acetaldehyde oxidation is catalysed by acetyl-CoA synthetase and is discussed below.

The metabolism of malonate to acetyl-CoA. Pseudomonas AMI grows on malonate with a mean generation time of 7 to $10 \mathrm{~h}$, and whole cells oxidized this substrate with a $\mathrm{QO}_{2}$ of approx. $20 \mu \mathrm{I} \mathrm{h}^{-1}$ (mg dry wt) ${ }^{-1}$. No malonyl-CoA synthetase activity could be detected when malonate was used instead of acetate in the usual acetyl-CoA synthetase assay (see Methods). This result, together with the observation that a mutant lacking acetyl-CoA synthetase is unable to grow on malonate (see below), suggests that malonate is metabolized by decarboxylation to free acetate which is then activated to acetyl-CoA in a reaction catalysed by acetyl-CoA synthetase. This contrasts with the route in Pseudomonas fluorescens in which malonyl-CoA is decarboxylated to acetyl-CoA, the malonyl-CoA being formed by a specific malonyl-CoA synthetase (Wolfe, Ivler \& Rittenberg, 1954).

\section{The role of acetyl-CoA synthetase in growth of Pseudomonas AMI}

In Pseudomonas AMI, there is an acetyl-CoA synthetase which is induced sevenfold during growth on 3-hydroxybutyrate compared with its level during growth on methanol (Table 2). 
Table 2. Specific activities of acetyl-CoA synthetase, 'malate synthase' and malyl-CoA lyase in extracts of Pseudomonas AMI, and mutants ICT5I, ICT54 and ICT5IR

Extracts were prepared and assayed as described in Methods. Enzyme activities are expressed as nmol substrate used or product formed/mg protein per min.

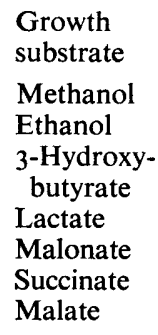

Growth substrate Ethanol 3-Hydroxybutyrate Lactate Succinate Malate

Acety
WT
$13 \cdot 4$
$20 \cdot 6$
$94 \cdot 6$
$39 \cdot 6$
$84 \cdot 5$
$\frac{15 \cdot 0}{15 \cdot 0}$

\begin{tabular}{cc} 
'MT & ICT5I \\
44 & I 9 \\
42 & - \\
35 & - \\
45 & $3 \cdot 4$ \\
26 & - \\
\hline 25 & $2 \cdot 0$
\end{tabular}

\begin{tabular}{|c|c|c|}
\hline \multicolumn{3}{|c|}{ Malyl-CoA lyase } \\
\hline WT & ICT5I & ICT5IR \\
\hline 840 & 920 & 1320 \\
\hline$\overline{210}$ & - & $\frac{-}{170}$ \\
\hline I 30 & 160 & 240 \\
\hline- & - & \\
\hline 200 & 160 & 120 \\
\hline- & - & - \\
\hline
\end{tabular}

No acetate kinase was detected in extracts of Pseudomonas AMI grown on any substrate. Assay of the acetyl-CoA synthetase in crude extracts suggested that the products of the reaction might be acetyl-CoA and ADP instead of the usual AMP and pyrophosphate. Such an enzyme would be able to function in the direction of acetate formation from acetyl-CoA, and free acetate might thus be important in the assimilation of acetyl-CoA produced during 3-hydroxybutyrate oxidation. To investigate this further, the enzyme was purified and characterized, and a mutant lacking the enzyme was isolated.

Partial purification and characterization of acetyl-CoA synthetase. Crude extracts of Pseudomonas AMI grown on 3-hydroxybutyrate catalysed the formation of coenzyme A esters from acetate, propionate and succinate, but not from 3-hydroxybutyrate, malonate, glycollate or malate. The relative rates were 70,38 , and $76 \mathrm{nmol} \mathrm{min}{ }^{-1} \mathrm{mg}^{-1}$ for acetate, propionate and succinate, respectively, in the standard acetyl-CoA synthetase assay. The acetyl-CoA synthetase was partially purified (sixfold) from these extracts by a procedure involving heating at $60{ }^{\circ} \mathrm{C}$, fractionating with ammonium sulphate, and gel-filtration on Sephadex Gi5o (see Methods). The ammonium sulphate fractionation removed succinylCoA synthetase and the final stage removed adenylate kinase. Using the purified preparation, it was shown that ADP was only produced during the acetyl-CoA synthetase reaction when adenylate kinase was added to the reaction mixture. The rate of ADP formation was then twice the rate of production of acetyl-CoA. Thus, in crude extracts, AMP, the product of the acetyl-CoA synthetase reaction gives rise to ADP by reaction with ATP catalysed by adenylate kinase. Acetyl-CoA was shown to be the product of the acetyl-CoA synthetase reaction by coupling its formation to $\mathrm{NADH}$ production in the presence of $\mathrm{NAD}^{+}$, malate, malate dehydrogenase and citrate synthase. The formation of propionyl hydroxamate, catalysed by crude extracts, in the acetyl-CoA synthetase reaction mixture containing propionate as substrate has not been investigated further; but the catalyst is probably acetyl-CoA synthetase, as found with acetyl-CoA synthetases from other sources (Jencks, I962).

Isolation and characterization of a mutant lacking acetyl-CoA synthetase. In order to elucidate the role of acetyl-CoA synthetase, a mutant (ICT54) lacking this enzyme (Table 2) was isolated by selecting for ability to grow on malate but not on a combination of acetate 


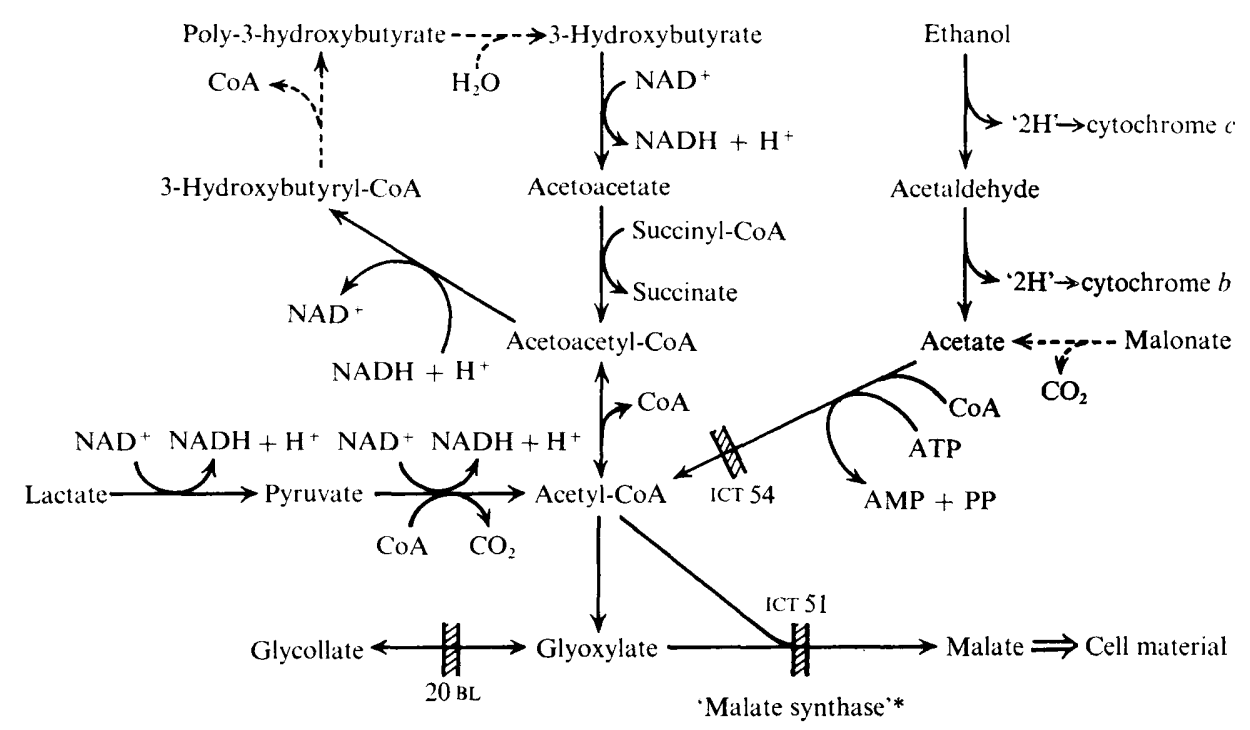

Fig. I. Pathways for assimilation of ethanol, malonate, 3-hydroxybutyrate, pyruvate and lactate in Pseudomonas AMI. Hatched bars indicate metabolic lesions in mutants. Reactions shown as dotted lines have not been investigated. * The 'malate synthase' activity is catalysed by malylCoA lyase and malyl-CoA hydrolase (Cox \& Quayle, 1976).

plus glyoxylate. Its succinyl-CoA synthetase activity was the same as that in wild-type Pseudomonas Ami. This mutant was unable to grow on ethanol, malonate or acetate plus glyoxylate but grew well on $\mathrm{C}_{1}$ compounds, 3-hydroxybutyrate, lactate, pyruvate, succinate or malate. These growth characteristics indicate that the relatively high levels of acetyl-CoA synthetase measured during growth of wild-type Pseudomonas AMI on 3-hydroxybutyrate do not indicate an essential role for the enzyme during this growth. The failure of mutant ICT54 to grow on ethanol or malonate indicates that free acetate is an intermediate in the oxidation of these substrates (Fig. I).

In bacteria grown on 3-hydroxybutyrate, the incorporation of radioactive acetate into metabolic intermediates by the mutant ICT54 was only $2 \%$ of that incorporated by the wild type (Table 3). This result was confirmed by growing bacteria on 3 -hydroxybutyrate in the presence of radioactive acetate for five generations: after this time, the specific activity (d.p.m./ $\mu \mathrm{g}$ dry wt) of mutant ICT54 was only I $5 \%$ of that measured with wild-type Pseudomonas AMI. Thus, acetate must be converted to acetyl-CoA before growth on ethanol, malonate or acetate plus glyoxylate can occur; and, during growth on 3-hydroxybutyrate, there is no route for oxidation of acetate to glyoxylate without the intermediacy of acetylCoA.

Demonstration that hydroxypyruvate reductase is not involved in the malate synthase pathway for assimilation of 3-hydroxybutyrate

It has been suggested that glycollate may be an intermediate in the oxidation of acetate to glyoxylate in Pseudomonas AMr, with the oxidation of glycollate to glyoxylate being catalysed by hydroxypyruvate reductase (Dunstan, Anthony \& Drabble, $1972 b$ ). However, a mutant (2OBL) lacking hydroxypyruvate reductase grew at the same rate as the wild-type bacteria on 3-hydroxybutyrate but had no detectable hydroxypyuvate reductase activity. Thus if glycollate is an intermediate, its oxidation to glyoxylate cannot be catalysed by 
Table 3. Distribution of radioactivity among components of the ethanol-soluble fraction of Pseudomonas AMI, and mutant ICT54 grown on 3-hydroxybutyrate and incubated with $\left[U-{ }^{14} C\right]$ acetate

\begin{tabular}{|c|c|c|c|}
\hline \multirow[b]{2}{*}{ Radioactive compound } & \multicolumn{3}{|c|}{ Radioactivity (d.p.m.) } \\
\hline & Wild type & ICT 54 & $20 \mathrm{OBL}$ \\
\hline $\begin{array}{l}\text { Malate } \\
\text { Succinate }\end{array}$ & $\begin{array}{l}9750 \\
6670\end{array}$ & $\begin{array}{r}1300 \\
\end{array}$ & $\begin{array}{r}10044 \\
6740\end{array}$ \\
\hline Fumarate & 13290 & \} 760 & 9010 \\
\hline Glycollate & 6350 & ND & 2810 \\
\hline Citrate & 7400 & ND & 6500 \\
\hline Aspartate & 16810 & ND & 12920 \\
\hline Glutamate & 404380 & 7680 & 260390 \\
\hline Alanine & 44770 & ND & 20630 \\
\hline Others & - & 1230 & - \\
\hline Total & 502920 & 10970 & 322600 \\
\hline$\%$ wt incorporation & 100 & $2 \cdot I$ & $62 \cdot 0$ \\
\hline glycollate/malate & 0.65 & - & 0.28 \\
\hline
\end{tabular}

ND, No radioactive peaks detected.

hydroxypyruvate reductase. The demonstration that the $\left[{ }^{14} \mathrm{C}\right]$ glycollate: $\left[{ }^{14} \mathrm{C}\right]$ malate ratio was lower in mutant $20 \mathrm{BL}$ than in wild-type bacteria incubated with $\left[{ }^{14} \mathrm{C}\right]$ acetate (Table 3) supports the suggestion that some of the glycollate in experiments with wild-type Pseudomonas AMI may arise by reduction of glyoxylate catalysed by hydroxypyruvate reductase (Anthony, 1975a).

The role of malate synthase in the growth of Pseudomonas AMI on 3-hydroxybutyrate, ethanol and malonate

In an attempt to confirm the proposed role for malate synthase during growth of Pseudomonas AMI on 3-hydroxybutyrate, ethanol and malonate, mutant ICT5I which lacked malate synthase activity (Table 2) was isolated by the same procedure as that described for mutant ICT54. Mutant ICT5I grew on the same substrates as wild-type bacteria (including $\mathrm{C}_{1}$ compounds, pyruvate, lactate and succinate) except for ethanol, malonate or 3-hydroxybutyrate, thus demonstrating a requirement for malate synthase activity during growth of Pseudomonas AMI on these three substrates. The virtual absence of the enzyme from mutant ICT5I grown on methanol confirms that malate synthase activity is not required for methylotrophic growth despite its presence in wild-type Pseudomonas AMI on all growth substrates (Table 2). A revertant of mutant ICT5I was isolated and was able to grow on ethanol, malonate, 3-hydroxybutyrate and acetate plus glyoxylate. Unexpectedly, extracts of the revertant grown on these compounds contained no detectable malate synthase activity.

\section{DISCUSSION}

Our results show that ethanol, malonate and 3-hydroxybutyrate are assimilated in Pseudomonas AMI by the routes shown in Fig. I. The pathway for oxidation of 3-hydroxy- 
butyrate to acetyl-CoA is essentially similar to that found in other bacteria (Senior \& Dawes, 1973; Oeding \& Schlegel, 1973). The oxidation of ethanol to acetate is catalysed by the same enzymes that catalyse methanol oxidation to formate; and is followed by the acetyl-CoA synthetase reaction to give acetyl-CoA. This route contrasts with that found in another methylotroph growing on ethanol (Hyphomicrobium $\mathrm{x}$ ) in which an NAD-linked dehydrogenase catalyses ethanol oxidation to acetaldehyde which may then be oxidized to acetyl-CoA by a CoA,NAD ${ }^{+}$-dependent acetaldehyde dehydrogenase or by the sequential action of an $\mathrm{NAD}^{+}$-linked acetaldehyde dehydrogenase and acetyl-CoA synthetase (Attwood \& Harder, 1974).

The oxidation of pyruvate to acetyl-CoA by Pseudomonas AMI is catalysed by a typical pyruvate dehydrogenase, and the necessity for complete oxidation of acetyl-CoA by enzymes of the TCA cycle during growth on multicarbon compounds has been demonstrated previously (Taylor \& Anthony, 1976).

The most difficult results to interpret are those involving measurements of 'malate synthase' activity. The preceding paper (Cox \& Quayle, 1976) shows that this activity in Pseudomonas AMI is due to the combined action of malyl-CoA lyase (catalysing condensation of acetyl-CoA and glyoxylate) and malyl-CoA hydrolase, and that mutant ICT5I has an altered hydrolase activity. Our results with this mutant suggest that 'malate synthase' activity is usually essential for growth of Pseudomonas AMI on ethanol, malonate and 3hydroxybutyrate, but not for growth on pyruvate and lactate. Pyruvate is assimilated by decarboxylation to acetyl-CoA but not by carboxylation to $\mathrm{C}_{4}$ compounds, and it has been suggested that the 'malate synthase' pathway operates for synthesis of $\mathrm{C}_{4}$ compounds during growth on pyruvate and lactate (Salem et al., I973 $b$ ). The results with revertant ICT5IR, which has the growth properties of wild-type bacteria but has not regained wildtype malyl-CoA hydrolase activity (Cox \& Qualye, 1976) and hence 'malate synthase' activity, suggest that there is an alternative route for the assimilation of acetyl-CoA in revertant ICT5IR and this might also operate during growth of Pseudomonas AMI on pyruvate and lactate (see Taylor, 1975). The alternative route might also operate during growth on ethanol, malonate and 3-hydroxybutyrate of mutant РCT57, which grows on all substrates except $C_{1}$ compounds but lacks malyl-CoA lyase (Salem, Hacking \& Quayle, 1974) and hence 'malate synthase' activity (Cox \& Qualye, I976). The nature of the alternative route(s), and the regulatory factors determining whether or not it operates during growth of mutants and of wild-type Pseudomonas AMI, are not known.

We thank Professors K. A. Munday and M. Akhtar for their encouragement in this work and the Science Research Council for a grant to C. Anthony.

\section{REFERENCES}

Anthony, C. (1975a). The biochemistry of methylotrophic micro-organisms. Science Progress $($ Oxford) 62, I 67-206.

Anthony, C. (1975b). The microbial metabolism of $\mathrm{C}_{1}$-compounds: the cytochromes of Pseudomonas AMI. Biochemical Journal 146, 289-298.

AtTwOod, M. M. \& HARDER, W. (1974). The oxidation and assimilation of $\mathrm{C}_{2}$-compounds by $\mathrm{Hypho}_{\text {- }}$ microbium sp. Journal of General Microbiology 84, 350-356.

Cox, R. B. \& QuAYLe, J. R. (1976). Synthesis and hydrolysis of malyl-coenzyme A by Pseudomonas AmI: an apparent malate synthase activity. Journal of General Microbiology 95, I 2 I-133.

DAwes, E. A. \& Foster, S. (1956). The formation of ethanol in Escherichia coli. Biochimica et biophysica acta 22, 253-265.

Dixon, G. H. \& Kornberg, H. L. (1959). Assay methods for key enzymes of the glyoxylate cycle. Biochemical Journal 72, $3 \mathrm{P}$. 
Dunstan, P. M. \& Anthony, C. (1973). Microbial metabolism of $C_{1}$ - and $C_{2}$-compounds: the role of acetate during growth of Pseudomonas AMI on $\mathrm{C}_{1}$-compounds, ethanol and $\beta$-hydroxybutyrate. Biochemical Journal 132, 797-80I.

Dunstan, P. M., Anthony, C. \& Drabble, W. T. (1972a). Microbial metabolism of $\mathrm{C}_{1}-$ and $\mathrm{C}_{2}$-compounds: involvement of glycollate in metabolism of ethanol and of acetate by Pseudomonas AMI. Biochemical Journal 128, 99-106.

Dunstan, P. M., Anthony, C. \& Drabble, W. T. (1972 b). Microbial metabolism of $\mathrm{C}_{1}$-and $\mathrm{C}_{2}$-compounds: the role of glyoxylate, glycollate and acetate in the growth of Pseudomonas AMI on ethanol and on $\mathrm{C}_{1}$-compounds. Biochemical Journal 128, 107-1 15.

HePtinstall, J. \& QUAYLE, J. R. (1970). Pathways leading to and from serine during growth of Pseudomonas AMI on $C_{1}$-compounds or succinate. Biochemical Journal $117,563-572$.

Jencks, W. P. (1962). Acyl activation. In The Enzymes, 2nd edn, vol. 6, pp. 373-385. Edited by P. D. Boyer, H. Lardy and K. Myrback. New York \& London: Academic.

Jones, M. E. \& Lipmann, F. (1955). Aceto-CoA-kinase. In Methods in Enzymology, vol. I, pp. 585-590. Edited by S. P. Colowick and N. O. Kaplan. New York: Academic.

Kaufman, S. (1955). P-enzyme. In Methods in Enzymology, vol. 1, pp. 718-722. Edited by S. P. Colowick and N. O. Kaplan. New York: Academic.

OEdING, V. \& SCHLEgel, H. G. (1973). $\beta$-ketothiolase from Hydrogenomonas eutropha HI 6 and its significance in the regulation of poly- $\beta$-hydroxybutyrate metabolism. Biochemical Journal 134, 239-248.

Ritchie, G. A. F., Senior, P. J. \& Dawes, E. A. (197I). The purification and characterization of acetoacetylCoA reductase from Azotobacter beijerinckii. Biochemical Journal 121, 309-316.

Rose, I. A. (1955). Acetokinase. In Methods in Enzymology, vol. I, pp. 591-595. Edited by S. P. Colowick and N. O. Kaplan. New York: Academic.

Salem, A. R., Hacking, A. J. \& Quayle, J. R. (1973a). Cleavage of malyl-CoA to acetyl-CoA and glyoxylate by Pseudomonas AMI and other $C_{1}$-utilizing bacteria. Biochemical Journal 136, 89-96.

Salem, A. R., Wagner, C., Hacking, A. J. \& Quayle, J. R. (I973b). The metabolism of lactate and pyruvate by Pseudomonas AMI. Journal of General Microbiology 76, 375-388.

Salem, A. R., Hacking, A. J. \& QuAyle, J. R. (1974). Lack of malyl-CoA lyase in a mutant of Pseudomonas AMI. Journal of General Microbiology 81, 525-527.

SCHuster, C. W. \& DoudorofF, M. (I962). A cold-sensitive $D(-)$ - $\beta$-hydroxybutyric acid dehydrogenase from Rhodospirillum rubrum. Journal of Biological Chemistry 237, 603-607.

Senior, P. J. \& DAWES, E. A. (1973). Regulation of poly- $\beta$-hydroxybutyrate metabolism in Azotobacter beijerinckii. Biochemical Journal 134, 225-238.

Simon, E. J. \& SHemin, D. (I953). Preparation of succinyl-coenzyme A. Journal of the American Chemical Society 75, 2520-2521.

SRERE, P. A. (1969). Citrate synthase. In Methods in Enzymology, vol. I 3, pp. 3-I I. Edited by J. M. Lowenstein. New York and London: Academic.

Stern, J. R., Coon, M. J., del Campillo, A. \& Schneider, M. C. (1956). Enzymes of fatty acid metabolism. 4. Preparation and properties of coenzyme A transferase. Journal of Biological Chemistry 221, I 5-3I.

TAYLOR, I. J. (1975). The microbial metabolism of $C_{1}$ and $C_{2}$ compounds. Ph.D. thesis, University of Southampton.

TAYloR, I. J. \& ANThony, C. (1975). Microbial metabolism of $\mathrm{C}_{1}$ - and $\mathrm{C}_{2}$-compounds; mutants of Pseudomonas AMI lacking malate synthase and acetyl-CoA synthetase. Proceedings of the Society for General Microbiology 2, 52-53.

TAYLOR, I. J. \& ANTHONY, C. (1976). A biochemical basis for obligate methylotrophy: properties of a mutant of Pseudomonas AMI lacking 2-oxoglutarate dehydrogenase. Journal of General Microbiology 93, 259-265.

Widdowson, D. \& ANTHONY, C. (1975). The microbial metabolism of $\mathrm{C}_{1}$-compounds: the electron transport chain of Pseudomonas AMI. Biochemical Journal 152, 349-356.

Wolfe, J. B., IVleR, D. \& Rittenberg, S. C. (1954). Malonate decarboxylation by Pseudomonas fluorescens. 2. Magnesium dependency and trapping of active intermediates. Journal of Biological Chemistry 209, 875-883. 